\title{
Placental Alkaline Phosphatase in Tumour Tissue and Serum
}

\author{
By Ellen Mössner, G. Pfleiderer \\ Institut für Organische Chemie, Biochemie und Isotopenforschung der Universität Stuttgart and
}

\author{
K. D. Dittel \\ Chirurgische Abteilung des Marienhospitals, Stuttgart
}

(Received December 23, 1983/March 27, 1984)

\begin{abstract}
Summary: Using immunochemical techniques, alkaline phosphatase isoenzymes were determined in tissue samples of breast carcinomas and carcinomas of the gastrointestinal tract. In breast carcinomas only $19 \%$ of the patients expressed significant placental alkaline phosphatase activity, compared with $78 \%$ in gastrointestinal tumours. The intestinal isoenzyme was found in $50 \%$ of the breast carcinomas and in nearly all of the other examined tissues. The two isoenzymes usually represent $1 \%$ of the total alkaline phosphatase activity, but in a few cases they may constitute between 10 and $90 \%$. In the serum of the patients under examination, elevated total alkaline phosphatase activity was found in only $7 \%$, and elevated placental alkaline phosphatase in $6 \%$ of the cases. No cases of elevated serum intestinal alkaline phosphatase were found. We therefore consider that serum placental alkaline phosphatase is a poor tumour marker for a general screening.
\end{abstract}

\section{Placentare alkalische Phosphatase in Tumorgewebe und Serum}

Zusammenfassung: In Gewebeproben von Mamma-Carcinomen als auch Carcinomen des Gastrointestinaltraktes wurden mit empfindlichen immunologischen Methoden die Isoenzyme der alkalischen Phosphatase bestimmt. Bei Brustkrebs zeigten nur 19\% der Patienten signifikante Aktivität der placentaren alkalischen Phosphatase, verglichen mit $78 \%$ bei gastrointestinalen Tumoren. Das intestinale Isoenzym wurde in $50 \%$ bei Brustcarcinom und in nahezu allen anderen malignen Geweben gefunden.

Meist betrug die katalytịche Aktivität der beiden Isoenzyme unter 1\% der gesamten katalytischen Aktivität der alkalischen Phosphatase, in wenigen Fällen zwischen 10 und 90\%. Im Serum der untersuchten Patienten wurde nur in $7 \%$ der Fälle überhaupt erhöhte katalytische Aktivität der gesamten alkalischen Phosphatase beobachtet, nur in $6 \%$ der Fälle placentare alkalische Phosphatase und in keinem der Fälle erhöhte intestinale alkalische Phosphatase gefunden. Wir glauben daher, daß die placentare alkalische Phosphatase für ein generelles Screening ein unbedeutender Tumormarker ist.

\section{Introduction}

Since its discovery as the Regan isoenzyme, serum placental alkaline phosphatase in a non-pregnant person has been considered to be a product of oncodevelopmental gene expression, and regarded as tumour marker (1). Owing to the use of different assay methods and the immunological cross-reactivity of the placental and intestinal alkaline phosphatase, controversy has arisen regarding the sensitivity of the placental alkaline phosphatase as a tumour marker.

With highly sensitive tests, low levels of placental alkaline phosphatase have been found in the sera of some healthy persons $(2,3)$, and slightly increased levels in smokers $(4,5)$. 
Also, placental alkaline phosphatase has been found as a minor component in the lung (6), testis (7), ovary $(8)$ and cervix $(9,10,6)$. Thus, in the normal adult, placental alkaline phosphatase might be produced by a slight expression of developmental genes, which is increased in cancer cells.

We developed a sensitive and easily performed immunoassay for the quantitative determination of placental alkaline phosphatase and also for intestinal alkaline phosphatase in serum and tissue extracts. In a screening test of 174 sera from treated cancer patients, we found elevated placental alkaline phosphatase values in only $10 \%$ of the samples (11). This unsatisfactory result led us to the quantitative determination of placental alkaline phosphatase in tumour tissue and its possible appearance in the sera of the patients prior to therapy and surgery.

\section{Materials and Methods}

\section{Biological materials}

Tissue samples were obtained at operation. Sera gained prior to surgery and the tissue were stored no longer than $24 \mathrm{~h}$ at $4^{\circ} \mathrm{C}$ or at $-20^{\circ} \mathrm{C}$ until used.

The tissue (samples between 0.3 and $8.0 \mathrm{~g}$ ) was homogenized in an ultra turrax homogenizer with $10 \mathrm{mmol} / \mathrm{l}$ Tris $/ \mathrm{HCl} \mathrm{pH} 7.5$, containing $2 \mathrm{mmol} / 1 \mathrm{MgCl}_{2}$ and $0.025 \mathrm{mmol} / 1 \mathrm{ZnCl}_{2}(1: 3 \mathrm{w} / \mathrm{v}), n$ butanol was added until a concentration of $30 \%$ was reached. After stirring at $4{ }^{\circ} \mathrm{C}$ for $48 \mathrm{~h}$ the homogenate was centrifuged $(40000 \mathrm{~g})$ and the aqueous layer, containing the enzyme, was dialysed against the homogenization buffer and used for analysis.

\section{Antibodies}

The IgG fraction of sheep anti-human intestinal alkaline phosphatase serum (Merck, Darmstadt) was isolated by $2 \times$ precipitation in $50 \%$ saturated $\left(\mathrm{NH}_{4}\right)_{2} \mathrm{SO}_{4}$ solution followed by dialysis against $10 \mathrm{mmol} / \mathrm{l} \mathrm{Tris} / \mathrm{HCl}$ buffer, $\mathrm{pH}$ 7.5. Anti-human placental alkaline phosphatase antibodies were raised in rabbits (titer: $25 \mathrm{U}$ placental alkaline phosphatase precipitated per $\mathrm{mg}$ IgG). The IgG fraction was isolated by affinity chromatography over protein Asepharose $\mathrm{Cl} 4 \mathrm{~B}$ : To a $8 \times 1 \mathrm{~cm}$ column, equilibrated with 10 $\mathrm{mmol} / \mathrm{l} \mathrm{Tris} / \mathrm{HCl}$ buffer, $\mathrm{pH} 7.5,4 \mathrm{ml}$ of serum was applied. After $1 \mathrm{~h}$ incubation, protein was eluted with the equilibration buffer. The bound IgG-fraction was eluted with $0.1 \mathrm{~mol} / 1$ glycine $/ \mathrm{HCl}$ buffer, pH 3.0. Fractions $(5 \mathrm{ml})$ were collected on ice and neutralised with $\left(\mathrm{NH}_{4}\right)_{2} \mathrm{CO}_{3}$. The total $\mathrm{IgG}$ fraction was concentrated by ultrafiltration to the original serum volume, then dialysed against a $10 \mathrm{mmol} / \mathrm{l}$ Tris/ $\mathrm{HCl}$ buffer, $\mathrm{pH} 7.5$.

Intestine alkaline solid-phase direct immuno assay

Polystyrene tubes $(50 \times 7 \mathrm{~mm}$, Greiner, Nürtingen) were coated with anti-intestinal alkaline phosphatase IgG by incubating them with $1 \mathrm{ml}$ of antibody solution $(10 \mathrm{mg} / \mathrm{l}$ in $10 \mathrm{mmol} / \mathrm{l}$ phosphate buffer, $\mathrm{pH}$ 7.0) for 2 days at room temperature. Non-absorbed antibodies were removed by suction and the tubes were washed three times with phosphate buffered saline $(9 \mathrm{~g} \mathrm{NaCl}, 0.27 \mathrm{~g}$ $\mathrm{KH}_{2} \mathrm{PO}_{4}, 1.43 \mathrm{~g} \mathrm{Na}_{2} \mathrm{HPO}_{4} \cdot \mathrm{H}_{2} \mathrm{O}$ ad $100 \mathrm{ml} \mathrm{H}_{2} \mathrm{O}, \mathrm{pH}$ 7.4). Tissue extracts $(900 \mu \mathrm{l})$ or serum $(100 \mu \mathrm{l})$ were pipetted into the tubes together with $800 \mu \mathrm{l}$ of $10 \mathrm{mmol} / \mathrm{l} \mathrm{Tris} / \mathrm{HCl}$ buffer $(\mathrm{pH} 7.5$, containing $2 \mathrm{mmol} / 1 \mathrm{MgCl}_{2}$ and $0.025 \mathrm{mmol} / \mathrm{Z} \mathrm{ZnCl} 2$ and $3 \%$ polyethylene glycol 6000 ) and the mixture was incubated for $1 \mathrm{~h}$ at $37^{\circ} \mathrm{C}$ followed by $24 \mathrm{~h}$ in the cold. After removing the solution by aspiration and washing three times with $1 \mathrm{ml}$ phosphate buffered sa- line, containing $3 \%$ polyethylene glycol 6000 , the enzymatic activity bound to the antibody-coated tube, was determined by incubating the tubes at $25^{\circ} \mathrm{C}$ in $900 \mu / 1 \mathrm{~mol} / 1$ diethanolamine $/ \mathrm{HCl}$, pH 9.8 containing $0.5 \mathrm{mmol} / 1 \mathrm{MgCl}, 10 \mathrm{mmol} / \mathrm{l} p$-nitrophenyl phosphate as substrate and $5 \mathrm{mmol} / \mathrm{l} L$-leucyl-glycyl-glycine to inhibit placental alkaline phosphatase. At a concentration of 5 $\mathrm{mmol} / \mathrm{l}$ this inhibitor inactivates $90 \%$ of the placental isoenzyme, but only $15 \%$ of the intestinal alkaline phosphatase. As only a part of the placental isoenzyme is bound to the anti-intestinal alkaline phosphatase coated tubes, a good discrimination is possible. After $60 \mathrm{~min}$ the reaction was stopped by addition of $100 \mu \mathrm{l} 5$ $\mathrm{mol} / \mathrm{l} \mathrm{NaOH}$, containing $10 \mathrm{mmol} / \mathrm{l} \mathrm{EDTA}$, and the absorbance was measured at $405 \mathrm{~nm}$ against a buffer blank. The enzymatic activity was referred to standard samples with known activity of the isoenzyme in $1.00 \mu \mathrm{l}$ serum or incubation buffer.

\section{Placental alkaline solid-phase direct immunoassay}

One $\mathrm{ml}$ of solution, containing $8 \mathrm{mg}$ anti-placenta alkaline phosphatase IgG in $3 \mathrm{mmol} / \mathrm{l}$ phosphate buffer, $\mathrm{pH} 6.3$, was added to an immuno-bead suspension (200 $\mathrm{mg}$ in $20 \mathrm{ml}$ buffer, Bio-Rad Laboratories, Richmond/CA) and incubated for $1 \mathrm{~h}$ at room temperature. To this $40 \mathrm{mg} 1$-ethyl(-dimethyl-amino propyl)-carbodiimide hydrochloride (EDAC) was added, mixed vigorously and stored at $4{ }^{\circ} \mathrm{C}$ for $3 \mathrm{~h}$. The mixture was equally divided amongst four $25 \mathrm{ml}$ centrifuge tubes and each aliquot was suspended in phosphate buffered saline to make $25 \mathrm{ml}$. The tubes were centrifuged at $1000 \mathrm{~g}$ for $10 \mathrm{~min}$. The supernatant was decanted, the pellet washed three times by suspension in phosphate buffered saline and centrifugation, followed by 2 washes in 1.4 $\mathrm{mmol} / \mathrm{l} \mathrm{NaCl} /$ phosphate buffered saline and 2 washes in phosphate buffered saline. The mixture was resupended in phosphate buffered saline and allowed to stand on ice for $3 \mathrm{~h}$ in order to renature the antibody. After centrifugation, the pellet was resuspended in $20 \mathrm{ml} 10 \mathrm{mmol} / \mathrm{l} \mathrm{Tris} / \mathrm{HCl}$ buffer, containing $2 \mathrm{mmol} / \mathrm{l}$ $\mathrm{MgCl}_{2}, 0.025 \mathrm{mmol} / \mathrm{Z} \mathrm{ZnCl}$ and $0.02 \% \mathrm{NaN}_{3}$. Protein determination in the supernatant revealed that, on average, $35 \%$ of the $\overline{I g G}$ fraction is coupled to the immuno-beads.

The bead suspension $(50 \mu \mathrm{l})$ (possessing covalently bound antiplacental alkaline phosphatase) was added to the serum or tissue extract. After 1 hour incubation at $37{ }^{\circ} \mathrm{C}$ and 2 washing and centrifugation steps (phosphate buffered.saline, containing 3\% polyethylene glycol $6000,10 \mathrm{~min} 1000 \mathrm{~g}$ ) the pellet was resuspended in $1 \mathrm{ml} 10 \mathrm{mmol} / \mathrm{l}$ Tris $/ \mathrm{HCl}$ buffer, $\mathrm{pH} 7.5$, containing $2 \mathrm{mmol} / \mathrm{l}$ $\mathrm{MgCl}_{2}, 0.025 \mathrm{mmol} / \mathrm{l} \mathrm{ZnCl}$ and $3 \%$ polyethylene glycol 6000 and heated for $90 \mathrm{~min}$ at $65^{\circ} \mathrm{C}$ to inactivate the partially bound intestinal isoenzyme. Placental alkaline phosphatase remains unaffected by this heating step, retaining $100 \%$ of its catalytic activity, while the intestinal isoenzyme is completely inactivated. With shorter heating periods, up to $10 \%$ of the intestinal alkaline phosphatase might be still active. After centrifugation for $10 \mathrm{~min}$ at $1000 \mathrm{~g}$, the pellet was resuspended in $900 \mu \mathrm{l} 1 \mathrm{~mol} / \mathrm{l}$ diethanolamine $/ \mathrm{HCl} \mathrm{pH} 9.8$ containing $0.5 \mathrm{mmol} / \mathrm{l} \mathrm{MgCl} 2$ and $10 \mathrm{mmol} / \mathrm{l}$ $p$-nitrophenyl phosphate. The catalytic activity was determined as described for intestinal alkaline phosphatase.

\section{Results}

Characterization of the solid phase direct immunoassays

Calibration curves with purified human intestinal alkaline phosphatase in the catalytic concentration range $0.2-3 \mathrm{U} / 1$ were linear, and the analytical recovery was about $70 \%$ when the enzyme was assayed in buffer, and $40-50 \%$ when the enzyme was assayed in serum. Samples with a catalytic concentration $>3 \mathrm{U} / \mathrm{l}$ were diluted in buffer. The intra=as- 
say coefficient of variation (determined in $100 \mu \mathrm{l} \mathrm{hu}$ man serum, $800 \mu l$ buffer with purified enzyme added) was $5.7 \%$ (mean $2.44 \mathrm{U} / \mathrm{l}, \mathrm{n}=10$ ).

This solid-phase assay, using antibody-coated tubes, could also be applied to the determination of placental alkaline phosphatase in tissue extracts. On the other hand, the low concentration of serum placental alkaline phosphatase might lead to poor analytical recoveries, using $1 \mathrm{ml}$ serum for the determination.

The immuno-beads assay for placental alkaline phosphatase determination (catalytic concentration range $=0.2-3 \mathrm{U} / \mathrm{l}$ ) showed an analytical recovery of $60-80 \%$ for enzyme standards in buffer or in $1 \mathrm{ml}$ serum. The intra-assay coefficient of variation (determined in $1 \mathrm{ml}$ human serum with purified enzyme added) was $3.3 \%$ (mean $0.3 \mathrm{U} / \mathrm{l}, \mathrm{n}=10$ ) and $5.0 \%$ (mean $2.2 \mathrm{U} / \mathrm{l}, \mathrm{n}=10$ ).
Alkaline phosphatase isoenzyme in cancerous tissues and sera of carcinomatoid patients

We determined total alkaline phosphatase catalytic concentration as well as the placental and intestinal isoenzyme in 170 sera of carcinomatoid patients prior to surgery or therapy, and in 111 tissue samples obtained by surgery. The results are summarized in table 1 and 2 . Serum intestinal and placental alkaline phosphatase catalytic concentrations up to $8 \mathrm{U} / 1$ or $0.4 \mathrm{U} / \mathrm{l}$ were regarded as negative; the detection limit for tissue extracts was $1 \mathrm{mU} / \mathrm{g}$ tissue.

Placental alkaline phosphatase was found in $20 \%$ of the breast carcinomas and in $75 \%$ of the gastrointestinal carcinomatoid tissues. In most cases, however, only a few $\mathrm{mU} / \mathrm{g}$ tissue placental alkaline phosphatase was detected (less than about $1 \%$ of the total alkaline phosphatase activity).

Tab. 1. Alkaline phosphatase isoenzymes in cancerous and benign tissue extracts.

\begin{tabular}{|c|c|c|c|c|c|c|c|c|}
\hline \multirow[b]{2}{*}{ Tissue } & \multirow[b]{2}{*}{$\mathbf{n}$} & \multirow{2}{*}{$\begin{array}{l}\text { Total alkaline } \\
\text { phosphatase } \\
\text { mU/g') } \\
\text { (mean value) }\end{array}$} & \multicolumn{3}{|c|}{ Placental alkaline phosphatase } & \multicolumn{3}{|c|}{ Intestinal alkaline phosphatase } \\
\hline & & & $\begin{array}{l}\left.\mathrm{mU} / \mathrm{g}^{\prime}\right) \\
\text { (mean value) }\end{array}$ & $\left.\mathrm{n}_{\mathrm{r}}{ }^{2}\right)$ & $\mathrm{n}-3.3)$ & $\left.\mathrm{mU} / \mathrm{g}^{\prime}\right)$ & $\left.n_{r}^{2}\right)$ & $n-3)$ \\
\hline Breast fibroma & 1 & 200 & 0 & 0 & 1 & 1 & 1 & 0 \\
\hline Breast carcinoma & 36 & $\begin{array}{l}200-5200 \\
(1007)\end{array}$ & $0-36$ & 5 & 31 & $0-11$ & 17 & 19 \\
\hline $\begin{array}{l}\text { Breast carcinoma } \\
\text { Bone metastasis }\end{array}$ & 9 & $\begin{array}{l}1500-6500 \\
(20522)\end{array}$ & $\begin{array}{l}0-2045 \\
(228)\end{array}$ & 4 & 5 & $\begin{array}{l}0-174 \\
(25)\end{array}$ & 8 & 1 \\
\hline Stomach benign & 4 & $\begin{array}{l}1100-4200 \\
(2000)\end{array}$ & 0 & 0 & 4 & $\begin{array}{l}1-882 \\
(234)\end{array}$ & 4 & 0 \\
\hline Stomach carcinoma & 19 & $\begin{array}{l}400-26300 \\
(3813)\end{array}$ & $\begin{array}{l}0-2000 \\
(178)\end{array}$ & 13 & 6 & $\begin{array}{l}0-1050 \\
(130)\end{array}$ & 18 & 1 \\
\hline Sigma diverticulitis & 3 & $\begin{array}{l}500-11000 \\
(733)\end{array}$ & $\begin{array}{l}0-4 \\
(2)\end{array}$ & 2 & 1 & $\begin{array}{l}6-18 \\
(13)\end{array}$ & 3 & 0 \\
\hline Sigma carcinoma & 11 & $\begin{array}{l}600-2000 \\
(1265)\end{array}$ & $\begin{array}{l}0-38 \\
(8)\end{array}$ & 10 & 1 & $\begin{array}{l}3-53 \\
(24)\end{array}$ & 11 & 0 \\
\hline Colon carcinoma & 12 & $500-11000$ & $0-76$ & 9 & 3 & $3-889$ & 12 & 0 \\
\hline Rectum carcinoma & 14 & $\begin{array}{l}140-6100 \\
(1310)\end{array}$ & $\begin{array}{l}0-18 \\
(2.5)\end{array}$ & 10 & 4 & $\begin{array}{l}0-94 \\
(21)\end{array}$ & 12 & 2 \\
\hline Broṅchial carcinoma & 1 & 95000 & 1 & 1 & 0 & 1 & 1 & 0 \\
\hline $\begin{array}{l}\text { Bronchial carcinoma } \\
\text { Bone metastasis }\end{array}$ & 1 & 3700 & 1 & 1 & 0 & 4 & 1 & 0 \\
\hline Gall bladder carcinoma & 2 & $1000-5200$ & $0-4$ & 1 & 1 & $0.2-21$ & 2 & 0 \\
\hline Duodenal carcinoma & 1 & 300 & 69 & 1 & 0 & 21 & 1 & 0 \\
\hline Kidney carcinoma & 1 & 1600 & 2 & 1 & 0 & 35 & 1 & 0 \\
\hline Ovarial carcinoma & 1 & 3700 & 104 & 1 & 0 & 22 & 1 & 0 \\
\hline
\end{tabular}

') $\mathrm{mU}$ alkaline phosphatase per gram tissue.

2) No. positive cases.

3) No. negative cases. 
Tab. 2. Alkaline phosphatase isoenzymes in sera of cancer patients.

\begin{tabular}{|c|c|c|c|c|c|c|c|}
\hline Diagnosis & $n$ & $\begin{array}{l}\text { Total } \\
\text { alkaline } \\
\text { phosphatase } \\
\text { U/l (range) }\end{array}$ & $\begin{array}{l}\text { No. of patients } \\
\left.>190 \mathrm{U} / \mathrm{I}^{1}\right)\end{array}$ & $\begin{array}{l}\text { Intestinal } \\
\text { alkaline } \\
\text { phosphatase } \\
\text { U/I (range) }\end{array}$ & $\begin{array}{l}\text { No. of patients } \\
\left.>8 \mathrm{U} / \mathrm{I}^{2}\right)\end{array}$ & $\begin{array}{l}\text { Placental } \\
\text { alkaline } \\
\text { phosphatase } \\
\text { U/l (range) } \\
\end{array}$ & $\begin{array}{l}\text { No. of patients } \\
>0.4\left(U / 1^{3}\right)\end{array}$ \\
\hline Breast carcinoma & 62 & $(28-246)$ & 2 & $(0-14.5)$ & 2 & $\left(\begin{array}{ll}0 & -0.7\end{array}\right)$ & 3 \\
\hline Stomach carcinoma & 29 & $(30-356)$ & 2 & $(0-2)$ & 0 & $(0-1.0)$ & 2 \\
\hline Rectum carcinoma & 21 & $(30-293)$ & 1 & $(0-2)$ & 0 & $\left(\begin{array}{ll}0 & -0.3\end{array}\right)$ & 0 \\
\hline Colon carcinoma & 20 & $(20-1337)$ & 1 & $(0-2)$ & 0 & $\left(\begin{array}{ll}0 & -0.3\end{array}\right)$ & 0 \\
\hline Sigma carcinoma & 20 & $(30-250)$ & 1 & $(0-2)$ & 0 & $(0-1.6)$ & 2 \\
\hline Seminoma & 4 & $(163-241)$ & 2 & 0 & 0 & $\left(\begin{array}{ll}0 & -9.6\end{array}\right)$ & 3 \\
\hline Bronchial carcinoma & 2 & $(89-93)$ & 0 & $(0-2)$ & 0 & $(0.2-0.8)$ & 1 \\
\hline Different carcinoma & 12 & $(42-651)$ & 3 & $(0-2)$ & 0 & $\left(\begin{array}{ll}0 & -0.5\end{array}\right)$ & 1 \\
\hline
\end{tabular}

1) Reference value 40-190 U/I (Merck, Klinisches Labor, see I.c. (17)).

2) Reference value 0- $8 \mathrm{U} / \mathrm{l}$ (see Mössner (11)).

3) Reference value 0- $0.4 \mathrm{U} / \mathrm{l}$ (see Mössner (11)).

This explains the poor positive results in sera: Placental alkaline phosphatase was detected in only $7 \%$ of the tested sera. In cases of carcinomatoid tissue with a very high placental alkaline phosphatase content $(1000 \mathrm{mU} / \mathrm{g}$ tissue, e.g. in one bone metastasis of a breast carcinoma and one stomach carcinoma) placental alkaline phosphatase was also found in the sera.

No placental alkaline phosphatase was detected in benign stomach or breast tissue, but it was present in 2 out of 3 tested cases of sigma diverticulitis. Intestinal alkaline phosphatase was detected (a few $\mathrm{mU} / \mathrm{g}$ tissue) in $50 \%$ of the breast carcinoma tissue and most bone metastases; as expected, it was also found in the intestinal tissue. The very variable intestinal alkaline phosphatase content of the stomach tissue, benign and cancerous, must be explained by the inclusion of duodenum tissue in the surgery samples.

Very high total alkaline phosphatase activity content $(15-65 \mathrm{U} / \mathrm{g}$ tissue) was found in 3 bone metastases of breast carcinomas and in 2 stomach carcinomas. With the exception of one bone metastasis, the latter tissue samples had only a little intestinal alkaline phosphatase and no placental alkaline phosphatase catalytic activity.

\section{Discussion}

Our experiments do not confirm the literature findings, that in cancer patients total alkaline phosphatase catalytic activity is raised and placental alkaline phosphatase is found quite frequently (12). In our patient collective (cancer of the breast and digestive tract), prior to any therapy, serum placental alkaline phosphatase was found in only $7 \%$ of 170 tested samples, and raised total alkaline phosphatase catalytic activity occurred with similar low frequency.
Owing to the sensitivity of the immunoassays used, the placental isoenzyme was detected in various normal tissues and in a few normal sera, where it represented a low percentage of total alkaline phosphatase activity. We measured placental alkaline phosphatase in over $50 \%$ of the examined tumour tissues, but in most cases the enzyme appeared in such a low catalytic concentration that its release into serum by cell turnover would give undetectable serum levels; with even more sensitive tests it might be shown to be in the range found in normal serum. In accordance with literature data $(13,14)$ we found, in the few samples tested (see also l.c. (11)), a good corre= lation between seminoma patients and serum placental alkaline phosphatase. Most of the gastrointestinal tumours showed the placental isoenzyme in the tissue, but not in the sera. Especially in these cases the high intestinal alkaline phosphatase content of the intestinal mucosa compared with the low intestinal alkaline phosphatase in fasted individuals, which shows a dependence on blood grouping and secretory status (15), must be kept in mind. These factors have never been considered in relation to serum placental alkaline phosphatase, but high intestinal alkaline phosphatase catalytic activity has been measured in faeces (16). Thus, placental alkaline phosphatase expressed in intestinal tumours might also reflected in the faecal excretion of the enzyme.

No placental alkaline phosphatase was found in benign stomach tissue, but it was found in $60 \%$ of the examined stomach carcinomas and in $75 \%$ of intestinal carcinomas, and in sigma diverticulitis.

Demonstration of a low placental alkaline phosphatase catalytic activity. is not necessarily related to cancerous tissue. Measured in sera, placental alkaline phosphatase must be regarded as an unsatisfactory tumour marker. 


\section{References}

1. Fishman, M. H., Inglis, N. J., Green, S., Anstiss, C. C., Gosh, N. K., Reif, A. E., Rustigan, R., Krant, M. J. \& Stolback, C. C. (1968) Nature 219, 697-699.

2. Haije, W. G., Murwaldt, J. H., Talerman, A., Umpers, T. J., Baggerman, L., Teelew, A. H., van der Pompe, W. B. \& van Driel, J. (1979) Int. J. Cancer 24, 288.

3. Usategui-Gomez, M. (1974) Cancer Research 34, 2544.

4. Tonih, S. E., Ortmeyer, A. E., Shindilman, J. E. \& Sussman, H. H. (1983) Int. J. Cancer 31, 51-53.

5. Maslow, W. C., Muensch, H. A., Azawa, F. \& Schneider, A. S. (1983) Clin. Chem. 29, 260-263.

6. Goldstein, D. J., Cramer, P. \& Hillert, U. (1982) Z. Gastroenterol. 18, 208-215.

7. Chang, C. H., Angellis, D. \& Fishman, W. H. (1980) Cancer Res. 40, 1506-1510.

8. Schnek, R. (1982) Diplomarbeit Stuttgart.

9. Malkin, A., Kellen, I. A. \& Caplan, B. (1979) Carcino-Embryonic Proteins (F.-G. Lehmann, ed.) Vol. 2, 679, Elsevier, Amsterdam.
10. Nozawa, S., Ohta, H., Izumi, S., Hayashi, S., Tsutsui, F., Kurihara, S. \& Watanabe, K. (1980) Acta Histochem. Cytochem. 13, 521 .

11. Mössner, E. \& Pfleiderer, G. (1983) Clin. Biochem. 16, 28-30.

12. Lehmann, F.-G. (1975) Klin. Wochenschrift 53, 585-587.

13. Wahren, B., Homsen, P. A. \& Stigbrand, T. (1979) Int. J. Cancer 24, 749-753.

14. Lange, P. H., Milan, J. L., Stigbrand, T., Vessella, R. L., Ruoslahti, E. \& Fishman, W. H. (1982) Cancer Res. 42, 3244.

15. Langmann, M. J. S., Leuthorld, E., Robson, E. B., Harris, J., Luffman, J. E. \& Harris, H. (1966) Nature 212, 41-43.

16. Lehmann, F.-G., Cramer, P. \& Hillert, U. (1980) Z. Gastroenterol. 18, 208-215.

17. Schlebusch, H., Rick, W., Lang, H. \& Knedel, M. (1974) Dtsch. Med. Wochenschr. 99, 765.

$$
\begin{aligned}
& \text { Professor Dr. Gerhard Pfleiderer } \\
& \text { Institut für Organische Chemie } \\
& \text { Biochemie und Isotopenforschung } \\
& \text { der Universität Stuttgart } \\
& \text { Pfaffenwaldring } 55 \\
& \text { D-7000 Stuttgart } 80
\end{aligned}
$$


$\therefore$. 